\title{
Report of the 51st Annual General Meeting of the Indian Institute of Welding
}

The 51st Annual General Meeting of the Institute was held on Saturday, the 23rd September, 2017 at 5:30 PM at the Auditorium of the hotel, The Stadel, Yuba Bharati Krirangan, Salt Lake Stadium, Kolkata. This was attended by 53 members.

After the Meeting was called to order by the President Mr. R. Srinivasan, Mr. Parimal Biswas, the Hony. Secretary General read out the Notice of convening the 51st Annual General Meeting of the Institute. Mr. Paramesh Krishna Dutta, the Hony. Treasurer apprised the members of the financial position of the institute. Mr. Dutta then read out the salient features of Auditors Report as well as Report of Finance Committee as printed in the 51st Annual Report of the Institute. Mr. Dutta then informed the Financial Position of the Head Office and the Branches for the year 2016-17. On the whole, after meeting the expenses against income received, the net Expenditure over Income was to the tune of Rs.11,23,847.09. The General Body approved the same after due deliberations.

After this, Hony. Secretary General read out the salient points of the Annual Report of the Council for the year 2016-17.

\section{IIW-2016 Annual Assembly}

The 69th IIW Annual assembly was held at Melbourne, Australia from 10th to 15th July 2016 in which 675 delegates attended the event. Sudan has become a new member. A five member delegation from IIW-India headed by Mr. R. Srinivasan, the President, Mr Parimal Biswas, the Hony. Secretary General, Mr. B. K. Mishra, the Chairman, ANBCCIndia, Mr. B. K. Das, the Chairman, ANB-India and Dr. Visvesh Badheka, Assistant Professor, PDPU, Gandhinagar, Gujarat represented the country.

\section{Indian Welding Journal}

Indian Welding Journal under the Chairmanship of Mr. Debaprasad Hajra and Chief Editor Prof. Santanu Das had been progressing satisfactorily.

\section{NATIONAL WELD MEET-2016}

One and half day National Weld Meet was organised by IIWIndia, Pune Branch jointly with College of Engineering, Pune on Saturday, the 27th of August, 2016 at the COEP Auditorium, Pune. The theme of the NWM-2016 was "Role of Welding on MAKE IN INDIA".
The inaugural function started with the National Anthem which was followed by traditional Lighting of Lamps. The inauguration was done by Mr. G. K. Pillai, M.D. \& CEO, Walchandnagar Industries Ltd. who was the Chief Guest on the occasion. He also released the souvenir and Bulletin of the Pune Branch, "Weld Mantra". Among the Honorable guests were Mr. S. L. Patil - Dean, College of Engineering, Pune and Mr. Deshwandker, who gave away awards to the toppers of Material Science and Metallurgy students. Mr. R. Srinivasan, the President of the IIW-India and Mr. Parimal Biswas, the Hony. Secretary General were also present and addressed the gathering. Altogether, 14 Technical Papers were presented on the theme of the meet in 3 sessions, and one paper to be adjudged the Best would be eligible for "AWPM Award". 205 delegates from various industries and 40 students participated in the meet.

\section{NATIONAL WELDING SEMINAR- 2016}

After a gap of 7 long years, Kolkata Branch of IIW-India organized the mega event of National Welding Seminar (NWS 2016) at Science City, Kolkata, the largest science centre in the Indian Subcontinent under National Council of Science Museums, along with the concurrent event, WELD INDIA 2016 - 11th International Welding Technology Exhibition held at Milan Mela, the fair ground opposite to Science City. The theme of this year's National Welding Seminar was "Challenges and Developments in Welding and Fabrication Technology". It was really a great challenge to organize such events in the current national scenario; even then, these events attracted large gathering of Scientists, Technologists, Research scholars, Practicing Engineers, Professionals, Students and Academicians from all over the country and abroad to know and share their knowledge about the welding science and technology. The Exhibition was a huge success, where the leading manufacturers from different welding sectors displayed their products, based on the latest technology.

On 15th December, Weld India Exhibition was inaugurated in the morning session by Mr. Sutanu Ghosh, President of The Bengal Chamber of Commerce and Industry. The welcome address was delivered by Mr. P. K. Das, Past President, IIW-India and Chairman, Organizing Committee. Then the speeches were delivered by Mr. Sutanu Ghosh, 
Mr. R. Srinivasan, the President, IIW-India, Mr. David McQuaid, the President, American Welding Society and Mr. Parimal Biswas, the Hony. Secretary General, IIW-India. All the speakers discussed about the importance of this type of exhibitions in brief. A total of 46 Exhibitors took part in the Exhibition.

In the afternoon of 15th December, the inaugural session of NWS 2016 took place in the mini auditorium of Science City in the presence of an august gathering. The Chief Guest of the event was Mr. G. K. Pillai, Managing Director and CEO, Walchandnagar Industries Limited. The Guests of Honour were Dr. Arun Kumar Bhaduri, Director, Indira Gandhi Centre for Atomic Research and Mr. Neeraj Kant, Managing Director, Indian Steel \& Wire Products. The occasion was chaired by Mr. R. Srinivasan. The welcome address of NWS 2016 was delivered by Mr. P. K. Das. Apart from these dignitaries, Mr. Parimal Biswas and Mr. David McQuaid were also present on the stage at the inaugural session. On this occasion, Mr. McQuaid presented a trophy to IIW-India for its notable presence in the welding fraternity. Since it was also the Golden Jubilee year, the role of IIW-India and its history of contribution to Nation Building was discussed by the speakers and was appreciated by all. The Keynote address was delivered by Mr. Pillai.

\section{Plenary Sessions}

Keeping in mind the 'Make in India' mission, a Special Plenary Session on Skill Development was organised on the 2 nd day of NWS, i.e., on 16th December in the morning session. This session was chaired by Mr. Sushim Banerjee, CEO, Indian Iron \& Steel Sector Skill Council. The Keynote address was delivered by Dr. Pradip Chakraborty, Director of Vocational Education and Training, Govt. of West Bengal. Cdr. J. S. Bhogal, Sr. Director, NABET, Quality Council of India, Mr. Ranajoy Banerjee, Executive Director, IIW-India, Mr. Nirbhay Srivastava, Assistant Director, Capital Goods Skill Council and Mr. S. Ghosh, Representative of M/s Quivan India Technical Institute were the other distinguished speakers. The whole spectrum about Skill Development in India by the Government, different Sector Skill Councils, Training Bodies and IIW-India were deliberated in this session through presentations and generated keen interest among the audience.

After the tea break, the 2nd Plenary Session was organized, which was chaired by Mr. D. V. Kulkarni, Chairman, Technical Committee, IIW-India. Among the speakers, the presentation of Prof. P. K. Ghosh, Deputy Director, IIT Roorkee, was on 'Knowledge of Pulse Current GMAW - A New Horizon to Welding Engineering'. The presentation of Mr. David McQuaid, President, AWS, was on 'Welding - A Global Bridge to the Future'. The presentation of Dr. Herbert Staufer, the Chairman, IIW Commission IV, was on 'Using Innovative CMT Process for Industrial Applications'.

Mr. P. Biswas informed that through out the year long program of the Institute, it was tried to rope in all spheres of people in India interested in welding science and technology.

- 6th IIW Research \& Consortium Colloquium of International Institute of Welding was held at Hyderabad during April 7-9 2016 where researchers and technocrats from various industries both from India and abroad participated in a 3-day program.

- Further, on the birthday of the Institute, that is on 22nd April, 2016, a day long program was organized at the hotel, The Stadel, Kolkata. A symposium on "Welding for Nation Building" was organized and eminent personalities in the welding field had shared their thoughts on different subjects. Felicitation to the Senior Members, Past Presidents, Vice Presidents, Hony. Secretaries was done. Some senior members were honoured with "Golden Jubilee Welding Ratna Award" and "Golden Jubilee Excellence Award for International Relations" to the overseas friends.

- The National Quiz Contest on "Metallurgy, Materials and Welding" for school students were organized at Chennai on 29th of July, 2016. Altogether 52 schools participated.

- Young Professionals Seminar on "Advances in Welding Technology and Automation" was organized by Baroda Branch at Ahmadabad on 1st October, 2016. The participants were engineering graduates of various fabrication industries under 40 -years of age.

- Young Engineers Competition was organized by Cochin Branch during 10-11 November, 2016. Altogether 11 industries participated with a team of 3-members to demonstrate their expertise and creative thinking, knowledge in technology, and professional acumen. All the participants had to excel both theoretically and oral presentation to express their ideas. The age limit had been restricted to 35-years for this competition.

At the request of the President, Mr. Parimal Biswas, Hony. 
Secretary General of the Institute then read out the notification of the Council under ref: IIW/C-1/2017-18 dated August 14th, 2017 which carried the list of qualified persons nominated by the Council in conformity with Article No. 36 of the Memorandum and Articles of Association of the Indian Institute of Welding for election of the members of the Council for the year 2017-18. As no other counter nomination received, the question of election did not arise and the Hony. Secretary General then formally announced the names of the members of the Council for the year 2017-18. Dr. Arun Kumar Bhaduri, Distinguished Scientist and Director, Indira Gandhi Centre for Atomic Research, Kalpakkam, Tamil Nadu, INDIA had been nominated as the President of the Institute for the year 201718 from Mr. R. Srinivasan.

The General Body then approved the appointment of M/s. T. K. Ghose \& Co. Chartered Accountants, as Auditor of the Institute until the next Annual General Meeting of the Institute at a fee of Rs.20,000/- (Rupees Twenty thousand only). This was followed by the farewell address of Mr. R. Srinivasan, the immediate Past President of the Institute. While thanking all for the support and cooperation extended to him throughout his tenure of 3-years. He thanked all the Office Bearers, Council
Members, Office Staff for their untiring help and co-operation to perform his responsibilities smoothly. He especially thanked Mr. Parimal Biswas, the Hony. Secretary General, for his continuous support right from the beginning. He also congratulated Dr. A. K. Bhaduri, Distinguished Scientist and the Director, IGCAR and also Director of the Board of International Institute of Welding to take over as the President of the Institute and expect IIW-India to play a leading role in the global platform. Then Dr. A. K. Bhaduri delivered his Presidential address to the members present. He stressed on increasing the membership of the Institute through reaching every corner of India. He also stressed on delivering proper services and support from the $\mathrm{HO}$ as well as from the Branches of the Institute. Further, he requested all members to participate whole heartedly in the International Congress 2017 (IC-2017) scheduled to be held at Chennai Trade Centre, Chennai from 7-9 December, 2017 on the theme "Advances in the Science, Technology and Skill Development in Welding" and also in the 12th International Welding Exhibition, WELDINDIA-2017 to be held at the same venue.

The 51st AGM concluded with vote of thanks moved by Mr. Parimal Biswas, the Hony. Secretary General of IIW-India.

\section{Appointment of new Assessor for assessment of IIW-India's Skill Development activity}

\section{Applications are invited from suitable candidates on Pan India basis for carrying out} assessments under IIW-India's Skill Development Programmes

\section{ELIGIBILITY CRITERIA}

- Education Qualification:

Essential:

i) Degree / Diploma / Licentiate in Mechanical / Electrical / Metallurgy / Chemical / Welding Technology / AMIIW

ii) Minimum experience in welding field:

a) 5-years for Degree holders

b) 10-years for Diploma holders

c) 15-years for ITI and others

- Professional Experience:

* Should have wide theoretical and practical knowledge of different welding process and basic aspect of welding technology

* Should be familiar with practical operation of the following welding processes:

Basic gas welding, Arc welding, TIG welding, $\mathrm{MAG} / \mathrm{CO}_{2}$ welding, Pipe welding (TIG+ARC), Gas cutting and Plasma Cutting.

* Physical attitudes: Should be physically fit to carry out welders testing activities in a shop for prolonged period of 8 to 10 hours. No optical disabilities like colour blindness or night blindness.

\section{Applications on plain paper may be sent to:}

The Indian Institute of Welding

Department of Skill Development

IIW-INDIA HOUSE, Plot No. 38, Geetanjali Park, 200, Kalikapur Main Road, Kolkata - 700099, INDIA | Email: sdp@iiwindia.com / iiw@iiwindia.com 